\title{
Isolation and characterization of mercury-resistant microbes from gold mine area in Mount Pongkor, Bogor District, Indonesia
}

\author{
WILHELMUS TERANG ARGA SANJAYA ${ }^{1}$, NUR SYAFIRA KHOIRUNNISA ${ }^{1}$, SRI ISMIANI ${ }^{1}$, \\ FAHRIZAL HAZRA ${ }^{1}$, DWI ANDREAS SANTOSA ${ }^{1,2, \varphi}$ \\ ${ }^{1}$ Department of Soil Science and Land Resources, Faculty of Agriculture, Institut Pertanian Bogor. Jl. Meranti, Kampus IPB Darmaga, Bogor 16680, \\ West Java, Indonesia, Tel.: +62-251-629360, 629354, Fax.: +62-251-629358, `email: dsantosa@indo.net.id \\ ${ }^{2}$ Research Center for Bioresources and Biotechnology, Institut Pertanian Bogor. Jl. Kamper, Kampus IPB Darmaga, Bogor 16680, West Java, Indonesia
}

Manuscript received: 11 March 2021. Revision accepted: 12 June 2021.

\begin{abstract}
Sanjaya WTA, Khoirunnisa NS, Ismiani S, Hazra F, Santosa DA. 2021. Isolation and characterization of mercury-resistant microbes from gold mine area in Mount Pongkor, Bogor District, Indonesia. Biodiversitas 22: 2656-2666. Exploring novel wild-type microbes is very important to give more flexibility for bioremediation implementation. It is related to discovering strain with higher detoxification ability and more reliable degradation mechanisms. Moreover, novel strain can be used as genetic material for strain development by molecular genetic engineering and production design formulation. The aims of this experiment were to characterize and identify new mercury-resistant microbes, investigate their capacity to accumulate mercury, and analyze the reducing mercury toxicity in bioassay. Four strains of bacteria selected through the screening stage were characterized for their morphological, biochemical, physiological, and molecular genetic characteristics. Considering their characteristics and mercury resistance levels, there are two selected microbial strains: fungus strain Cladosporium halotolerans $\mathrm{Hg} 32$ and the bacterial strain Mycolicibacterium peregrinum $\mathrm{Hg} 37$ with a mercury resistance level up to $3000 \mathrm{mg} \mathrm{L}^{-1}$. The $C$. halotolerans $\mathrm{Hg} 32$ could remove mercury with the highest potency up to $90.72 \%$ at a mercury concentration of $100 \mathrm{mg} \mathrm{L}^{-1}$, while $M$. peregrinum $\mathrm{Hg} 37$ removes up to $77.10 \%$ at mercury concentrations of 10 $\mathrm{mg} \mathrm{L}^{-1}$. Toxicity bioassay tests using fish confirmed that $C$. halotolerans $\mathrm{Hg} 32$ and M. peregrinum $\mathrm{Hg} 37$ had the ability to detoxify mercury in contaminated water. Both have successfully proven to reduce the mortality rate to below $5 \%$.
\end{abstract}

Keywords: ASGM, bioremediation, contamination, fish bioassay, mercury removal

Abbreviations: ASGM: Artisanal and Small-scale Gold Mining; MIC: Minimum Inhibitory Concentration; PCR: Polymerase Chain Reactions; AAS: Atomic Absorption Spectrophotometry

\section{INTRODUCTION}

Nowadays, mercury $(\mathrm{Hg})$ contamination extends to environments such as soils, sediments, seawater, etc. In soil environment, Krisnayanti et al. (2012) reported that soil at Sekotong District of West Lombok was contaminated by mercury ranging from 25 to $40 \mathrm{mg} \mathrm{kg}^{-1}$. It also caused plant poisoning symptoms (chlorosis, brown plant root, root hood damage) in the region, and the accumulation of mercury in plant seeds around $0.20 \mathrm{mg} \mathrm{kg}^{-1}$. Meanwhile, in aquatic environment of southeastern coast of the Mediterranean Sea, total dissolved mercury ranged from $0.04 \mu \mathrm{g} / \mathrm{L}$ to $6.09 \mu \mathrm{g} / \mathrm{L}$ has been reported causing mercury accumulation in the fish up to $0.77 \mu \mathrm{g} / \mathrm{g}$ on the Siganus luridus (Abdallah 2020). In general, the concentration level of mercury in fishes was influenced by feeding habitat for each species. While for the human, organic mercury compounds (methyl mercury and phenyl mercury) which are highly reactive and can attack the human nervous system through the bloodstream (Rasmussen et al. 2008).

The Mount Pongkor area is an area with the biggest Artisanal and Small-scale Gold Mining (ASGM) in Indonesia using mercury for gold leaching. There are 850 ASGM hotspots mined by more than 150.000 miners (Ismawati et al. 2013). The location of ASGM in Mount
Pongkor is similar to the majority of ASGM in Indonesia generally which take place at the upland area around rice fields or residence. It makes mercury easily transported through water flow from the upland to the lowland area.

Activity of ASGM at Mount Pongkor area is handled traditionally similar to other ASGM in Indonesia which excavate vertically and horizontally the soil. The gold is extracted by amalgamation technology using $\mathrm{Hg}$. Residual mud from the extraction process is usually reprocessed through cyanidation. Then, the residue is discharged into land around the site, even agricultural land (Suhartini and Abubakar 2017). Yoga et al. (2014) have reported that mercury contamination caused by ASGM in Cikaniki River was higher than the maximum limit. In Cisarua Village, $60 \%$ of villagers have been reported poisoned by mercury $(\mathrm{Hg})$ which was proven by mercury accumulation in their hair counted between 2.03 to $9.04 \mathrm{ppm}$ (Sumantri et al. 2014). Until 2015, the Ministry of Environment reported that $90 \%$ of land, including residential housing in Mount Pongkor area, has been contaminated by heavy metal (Ismawati et al. 2015).

Generally, there were three classes of the value range of the element mercury in active river sediments in the Mount Pongkor area, consisted of first-class around 18.5-220 ppm (ASGM Cikoret, Pasir Jawa and Ciguha), second class 
around 6-18.5 ppm (Cikaniki River and Cipanganten River) and third class interpreted as not polluted area (1-6 ppm). Meanwhile, the mercury concentration level in the soil was divided into three classes: first class (60-400 ppm), second class (10-60 ppm) and third class as not polluted area (1-6 ppm). The first category was located at PETI Cikoret, Pasir Jawa, Ciguha, around the Cipanganten River, around the Cikaradak River and around the Cimarinten River, and the second class has reported including around the Cikaniki River in the Cihiris area and around the Citeureup River (Juliawan 2006).

Several types of microbes and the mechanism of bioremediation of metal pollutants in the environment have been successfully carried out (Kiran et al. 2017; Retnaningrum and Wilopo 2017; Du et al. 2021). Metalresistant microbes have a critical role in optimizing bioremediation as an effective and low-cost alternative to removing metal pollutants, one of which is mercury. Many exploration results have been reported massively to support mercury remediation development. Hindersah et al. (2017) have isolated Azotobacter as mercury-resistant bacteria from mercury-contaminated agriculture soil on Buru Island, Maluku. Four bacteria that can accumulate mercury have been discovered in Mandor District, West Kalimantan. They consisted of Bacillus subtilis HgTA1 and HgTL2, Burkholderia cepacia HgRL, and Burkholderia cenosepacia HgRA (Ekyastuti and Setyawati 2015). In West Lombok, Brevundimonas vesicularis and Fusobacterium aquatile have been reported to have mercury accumulation ability by $75 \%$ in small-scale gold mine tailing with initial $\mathrm{HG}$ concentration $41.37 \mathrm{ppm}$ (Chasanah et al. 2018). Imron et al. (2019) isolated Pseudomonas aeruginosa from the Keputih non-active sanitary landfill leachate, which can be mercury-reducing agents in bioremediation. Apart from bacteria, several species of fungi have also been reported to have mercury resistance. Hindersah et al. (2018a) carried out the isolation of several species of fungi that are resistant to mercury from mercury-contaminated agricultural land. Meanwhile, Pietro-Souza et al. (2020) reported the role of endophytic fungi as bioremediation agents.

In the previous study in Mount Pongkor area, two mercury-resistant microbes (Brevundimonas sp. $\mathrm{HgP} 1$ and Brevundimonas sp. $\mathrm{HgP} 2$ ) have been discovered that can survive with a Minimum Inhibitory Concentration (MIC) of $575 \mathrm{ppm}$. They can accumulate $\mathrm{Hg}^{2+}$ at the stationary phase in the medium supplemented with $50 \mathrm{ppm}$ and 100 ppm $\mathrm{HgCl}_{2}$ (Irawati et al. 2012). However, based on preliminary exploration in 2017, some microbes have higher mercury resistance. There four microbes isolated from Mount Pongkor area can survive in the medium supplemented by $600 \mathrm{ppm} \mathrm{HgCl}_{2}$. In this study, four new microbes are isolated with higher MIC of 600-3000 ppm. The research aims to characterize new mercury-resistant microbes, to investigate their capability to accumulate mercury, and to analyze the reducing mercury toxicity in bioassay.

\section{MATERIALS AND METHODS}

\section{Study area}

The study area and sampling locations located in Mount Pongkor area, Bantar Karet Village, Nanggung Subdistrict, Bogor District, West Java Province, Indonesia are shown in Figure 1. Besides the gold mining company, villagers also mined Mount Pongkor area illegally and used mercury for gold purification. In the present study, soil samples were collected from five sampling sites (Table 1). All samples were collected using $0.5 \mathrm{~L}$ pre-sterilized glass containers with screw-cap lids, which were immediately stored at $-2^{\circ} \mathrm{C}$ upon arrival at the laboratory until they would be analyzed.
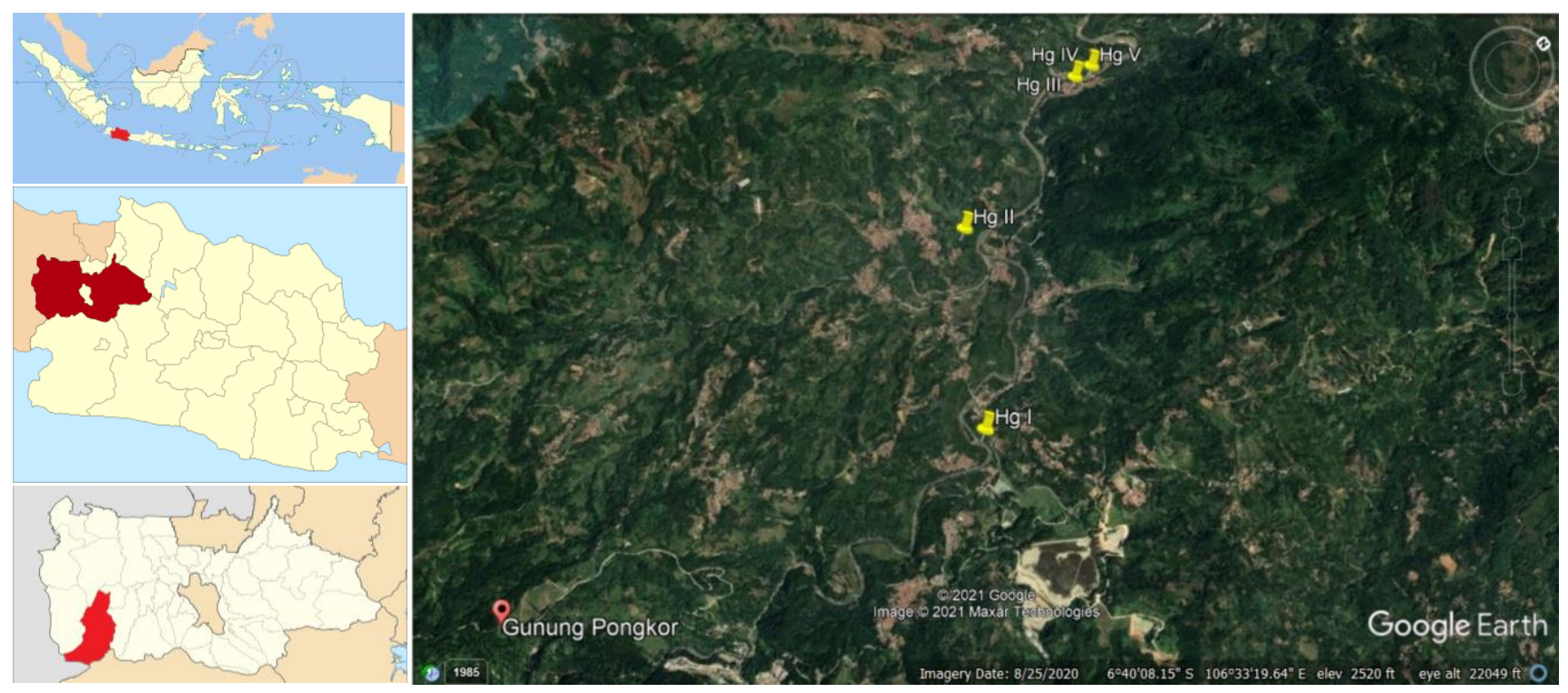

Figure 1. Location of the five sample point in Mount Pongkor area, Bantar Karet Village, Nanggung Sub-district, Bogor District, West Java Province, Indonesia 


\section{Isolation and selection of microbes}

Ten grams of soil sample was mixed with $90 \mathrm{~mL}$ of sterile $0.85 \% \mathrm{NaCl}$ solution for 30 minutes. Serial dilution was used for each sample up to seven concentrations $\left(10^{-1}\right.$, $10^{-2}, 10^{-3}, 10^{-4}, 10^{-5}, 10^{-6}$, and $\left.10^{-7}\right)$. Then $0.5 \mathrm{~mL}$ suspension was poured into a nutrient agar medium that had been supplemented with $10 \mathrm{mg} \mathrm{L}^{-1} \mathrm{HgCl}_{2}$, and then an incubation period was conducted for 48 hours. A single colony was inoculated using streak plate methods and incubated for 24 hours to obtain a pure isolate.

Generally, to define mercury resistance, the isolates that grew in the presence of $10 \mathrm{mg} \mathrm{L}^{-1} \mathrm{Hg}$ were considered to be mercury-resistant microbes. Stock solutions containing analytical grades of $\mathrm{HgCl}_{2}$ were prepared, filter-sterilized, and added to NB (Nutrient Broth) medium to obtain the final concentration levels provided (10-3000 $\mathrm{ppm} \mathrm{HgCl}_{2}$ NB composition used in the experimentation was $1 / 5$ normal recipe, consisting of $2 \mathrm{~g}$ peptone, $2 \mathrm{~g}$ beef extract, and $1 \mathrm{~g}$ sodium chloride in one liter water. The NB tubes were inoculated with the tested isolate and then incubated at $37{ }^{\circ} \mathrm{C}$ for $72 \mathrm{~h}$. The highest concentration of the tested mercury in which the isolate was able to grow was considered the maximum tolerable concentration (MTC).

\section{Morphological and biochemical characterization of mercury resistant microbes}

The collected bacteria were then subjected to biochemical tests that included carbohydrate fermentation, $\mathrm{H}_{2} \mathrm{~S}$ production, motility, oxygen consumption, citrate use, catalase, and oxidase test. A Carbohydrate fermentation test was conducted using $15 \%$ glucose, $0.5 \%$ lactose, and $0.5 \%$ sucrose media dissolved in $100 \mathrm{~mL}$ of peptone water$10 \% \mathrm{NaCl}$ and $1 \mathrm{~mL}$ of $0.1 \%$ bromothymol blue indicator. Each biochemical test was performed following standard procedures for microbial biochemical testing according to Cappuccino and Sherman (2002), Harley and Prescott (2005). Morphological characters were observed through microscopic observations with stereo microscopy to illustrate colony characteristics and compound microscopy for cell histological images.

\section{Molecular identification based 16S rRNA gene and ITS region analysis}

Identification of selected isolates was done by $16 \mathrm{~S}$ rRNA approach for bacteria and ITS 3 region for fungi. Genomic DNA was extracted using Presto ${ }^{\mathrm{TM}}$ Mini gDNA Bacteria Kit (Genaid). Amplification for 16S rRNA gene was achieved using two primers consisted of E8F: 5-AGA GTT TGA TCC TGG CTC-3 for forward and 1541R: 5AAG GAG GTG ATC CAG CCG CA-3 for reverse, while ITS region amplification used ITS-1: 5-TCC GTA GGT GAA CCT GCG G-3 as a forward primer and ITS-4: 5TCC TCC GCT TAT TGA TAT GC-3 as reverse primer in a 50 ul reaction volume using $1 \mathrm{U}$ Taq DNA polymerase (My Taq Red Mix, Bioline) in a My-Cycler thermal cycler (Bio-Rad) with the following program: initial denaturation at $95^{\circ} \mathrm{C}$ for 5 min followed by 35 cycles of $95^{\circ} \mathrm{C}$ denaturations for $30 \mathrm{sec}, 55^{\circ} \mathrm{C}$ of annealing for $30 \mathrm{sec}$, and extended to $72^{\circ} \mathrm{C}$ for $1.5 \mathrm{~min}$. A final extension step was set at $72^{\circ} \mathrm{C}$ for $10 \mathrm{~min}$. Amplified products were verified by agarose gel electrophoresis and Gel doc system (BioRad, USA). Verified DNA samples were sent to First Base (Malaysia) for DNA sequencing.

The initial sequence analysis was undertaken using the Basic Local Alignment Search Tool (BlastN). Phylogenetic analyses were carried out with MEGA X using Maximum Likelihood method. The tree was used maximum composite likelihood method for determining evolutionary distances (Tamura et al. 2013). After removing gaps and missing data, the multiple sequence alignment of 16SrRNA gene sequence was done employing ClustalW (Larkin et al. 2007). The evolutionary distances of harboring organisms were computed using the Poisson correction method.

\section{Mercury removal potential analyses}

Two microbes with the highest resistance ability (3000 $\mathrm{ppm}$ ) were selected for the mercury removal test. The mercury removal experiment was performed in $50 \mathrm{~mL}$ Nutrient Broth (NB) and Potato Dextrose Broth (PDB). Log phase microbes culture $\left(1 \times 10^{8}\right.$ cell $\left./ \mathrm{mL}\right)$ was inoculated into medium NB (for bacteria) and PDB (for fungi). The mercury's initial concentration was set to $500 \mathrm{ppm}, 1000$ ppm, $1500 \mathrm{ppm}, 2000 \mathrm{ppm}, 2500 \mathrm{ppm}, 3000 \mathrm{ppm}$ in the separate flask. All isolates were incubated at $37^{\circ} \mathrm{C}$ on a shaker condition of $120 \mathrm{rpm}$. Nutrient broth containing mercury was maintained as a negative control flask. Mercury removal from the nutrient broth was studied four days after inoculation. Mercury removal was determined by withdrawing the samples' aliquots from the flask (culture with mercury) at various concentration intervals. Sample centrifugation at $8,000 \mathrm{rpm}$ for 10 minutes was carried out to separate bacterial biomass and culture medium. Then, supernatant and pellets were moved separately, and stored at $0{ }^{\circ} \mathrm{C}$ for $\mathrm{Hg}$ quantification using Atomic Absorption Spectrophotometry (AAS) at Laboratory of Productivity and Aquatic Environment, IPB University, Indonesia. Mercury concentration measured in the supernatant represents soluble mercury in media, while mercury content in the pellet illustrates accumulated mercury in the cells.

Table 1. Altitude and coordinates of the five sampling point

\begin{tabular}{|c|c|c|c|}
\hline Location & Sample & Coordinate & $\begin{array}{c}\text { Heigh } \\
\text { (m) }\end{array}$ \\
\hline \multirow{5}{*}{$\begin{array}{l}\text { Mount } \\
\text { Pongkor } \\
\text { area }\end{array}$} & $\mathrm{Hg} \mathrm{I}$ & $-6^{\circ} 38^{\prime} 35^{\prime \prime}, 106^{\circ} 33^{\prime} 54^{\prime \prime}$ & 460 \\
\hline & $\mathrm{Hg}$ II & $-6^{\circ} 38^{\prime} 11^{\prime \prime}, 106^{\circ} 33^{\prime} 16^{\prime \prime}$ & 406 \\
\hline & $\mathrm{Hg}$ III & $-6^{\circ} 37^{\prime} 28^{\prime \prime}, 106^{\circ} 33{ }^{\prime} 2^{\prime \prime}$ & 385 \\
\hline & $\mathrm{Hg}$ IV & -637'23”, 106³3’2” & 349 \\
\hline & $\mathrm{Hg} \mathrm{V}$ & $-6^{\circ} 37^{\prime} 23^{\prime \prime}, 106^{\circ} 33^{\prime} 2^{\prime \prime}$ & 371 \\
\hline
\end{tabular}




\section{Toxicity bioassay of decontaminated water}

Toxicity Bioassay was tested in decontaminated water which has been detoxified by selected resistant isolates. It was carried out on cultured common crap (Cyprinus carpio) and western mosquitofish (Gambusia affinis). Fish were taken from an aquaculture pond and transferred to the laboratory aquarium using polythene bags. After transferring, the fish were acclimatized for one week before moving to the aquarium with treatmented water. There were three treatments including synthetic contaminated water (SCW) as positive control, no contaminated water as negative control, and decontaminated water by selected isolates. The SCW was water that has been added with $\mathrm{HgCl}_{2}$ to a concentration of $1 \mathrm{mg} \mathrm{L}^{-1}$ for C. carpio and 0.8 $\mathrm{mg} \mathrm{L}^{-1}$ for $G$. affinis. The decontaminated water was obtained from SCW which has already been inoculated by selected isolates and incubated four days before use. The fish were raised in treatmented water with an artificial aerator fitted to maintain oxygen levels for an e exposure time of $96 \mathrm{~h}$. Feeding was not carried out during exposure period. There were three treatments for each fish species with three replication units (aquarium set) for each treatment. Ten fishes with $50 \mathrm{~L}$ treatment water were put in each aquarium set. The fish used in the experiment had $8.42( \pm 0.51) \mathrm{g}$ for the average wet weight (SD). Environmental data measured consisted of dissolved oxygen $\left(\mathrm{mg} \mathrm{L}^{-1}\right)$, temperature $\left({ }^{\circ} \mathrm{C}\right)$, and $\mathrm{pH}$. Those data collections were observed individually in each aquarium at $24 \mathrm{~h}, 48 \mathrm{~h}, 72 \mathrm{~h}$, and $96 \mathrm{~h}$ incubation time to determine experimental tank water quality. Fish mortalities were recorded at 24, 48, 72, and $96 \mathrm{~h}$ of exposure, and the dead fish were removed regularly from the test solution.

\section{RESULTS AND DISCUSSION}

\section{Isolates of mercury resistant microbes}

Even though research related to mercury-resistant microbes from Mount Pongkor area have been carried out earlier by Irawati et al. (2012), we carried out it again to explore more pronouncedly. Sampling was done at the sediment area point, a microbial hotspot with a high exchangeable mercury ratio (Abdallah 2020). We discovered several isolates with higher resistance levels to mercury exposure in screening tests. In Earlier Brevundimonas sp. HgP1 (Accession Number JX009135) and Brevundimonas sp. $\mathrm{HgP} 2$ (Accession Number JX009136) had been reported as strains with mercury accumulation ability that could survive in medium supplemented by $575 \mathrm{ppm} \mathrm{HgCl}_{2}$. We used Lurient Bertani Agar medium with supplemented $10 \mathrm{ppm} \mathrm{HgCl}_{2}$ for screening 128 prospective isolates in this research. All 128 potential bacterial isolates were inoculated in Lurient Bertani Broth with the multilevel concentration of $\mathrm{HgCl}_{2}$ (50 ppm, 100 ppm, 200 ppm, 400 ppm, 500, and 600 ppm). Four selected bacteria survive in NB medium supplemented 600 ppm, including $\mathrm{Hg} 32, \mathrm{Hg} 37, \mathrm{Hg} 43$, and $\mathrm{Hg} 44$. The addition of mercury doses to the media in stages was continuously carried out until the microbial isolates could not grow.

Two isolates showed the highest resistance to mercury at concentrations up to $3000 \mathrm{ppm}$, while $\mathrm{Hg} 43$ has a resistance level of up to $800 \mathrm{ppm}$ and $\mathrm{Hg} 44$ by $1000 \mathrm{ppm}$ (Table 2). Based on resistant-mercury bacteria collected in Indonesia, none of the isolates could survive at the same mercury concentration level. It is also higher than two isolates isolated from Mount Pongkor area in the previous study (Irawati et al. 2012). In the other region of Indonesia, Febria et al. (2016) have isolated bacteria with the highest resistance mercury level from Sijunjung District; West Sumatra was only $250 \mathrm{ppm}$. Meanwhile, Ginting et al. (2021) have reported the highest resistance mercury level up to $170 \mathrm{ppm}$ around ex-gold mine tailings. The mercuryresistant fungus from contaminated agricultural soil in Buru Island had been reported to grow well at $25 \mathrm{ppm}$ (Hindersah et al. 2018a). In Egypt, Naguib et al. (2019) have reported that 14 isolates have the highest resistance to mercury at concentrations up to $160 \mathrm{ppm}$.

Table 2. Four selected isolates with the highest resistance to mercury

\begin{tabular}{cccc}
\hline $\begin{array}{c}\text { Isolated } \\
\text { code }\end{array}$ & Coordinated & $\begin{array}{c}\text { Height } \\
(\mathbf{m})\end{array}$ & $\begin{array}{c}\text { Resistant } \\
\text { level (ppm) }\end{array}$ \\
\hline $\mathrm{Hg} 32$ & $-6^{\circ} 37^{\prime} 28^{\prime \prime} ; 106^{\circ} 33^{\prime} 2^{\prime \prime}$ & 385 & 3000 \\
$\mathrm{Hg} 37$ & $-6037^{\prime} 23^{\prime}, ; 106033^{\prime} 2^{\prime \prime}$ & 349 & 3000 \\
$\mathrm{Hg} 43$ & $-6037^{\prime} 23^{\prime} ; 1060332^{\prime}$, & 349 & 800 \\
$\mathrm{Hg} 44$ & $-6037^{\prime} 23^{\prime} ; 1060332^{\prime}$, & 349 & 1000 \\
\hline
\end{tabular}
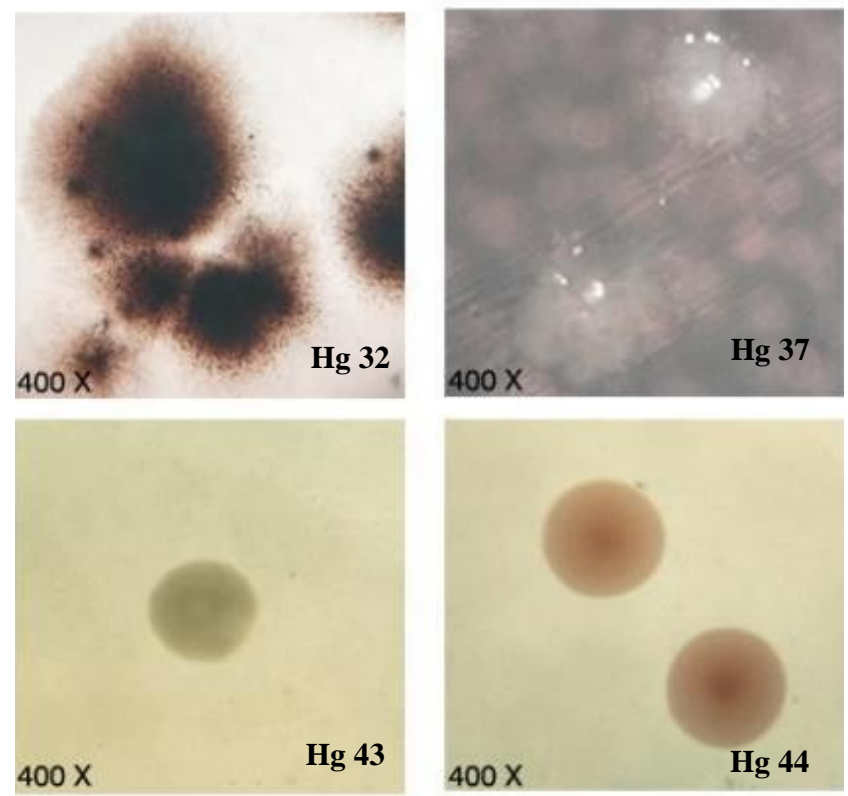

Figure 2. Colony shape under 400 times stereo microscope magnification 
Table 3. Morphological and physiological characteristic of Mercury-resistant microbes isolated from gold mine area in Mount Pongkor

\begin{tabular}{|c|c|c|c|c|}
\hline \multirow{2}{*}{ Characteristic } & \multicolumn{4}{|c|}{ Isolate code } \\
\hline & Hg32 & Hg37 & Hg43 & Hg44 \\
\hline Cell Morphology & $n / d$ & Coccus & Coccus & Bacil \\
\hline Colony Shape & Filamentous & Circular & Irregular & Circular \\
\hline Colony Elevation & Flat & Raised & Raised & Raised \\
\hline Colony Margin & Entire & Undulate & Entire & Entire \\
\hline Colony Color & Black & White & White & Red \\
\hline Colony Size & $1-1,5 \mathrm{~mm}$ & $0,5-0,7 \mathrm{~mm}$ & $0,9-1 \mathrm{~mm}$ & $0,5-0,9 \mathrm{~mm}$ \\
\hline Gram stain & $n / d$ & positive & positive & negative \\
\hline $\mathrm{PH}$ & $4-9$ & 4-8 & 4-8 & 4-8 \\
\hline Oxygen using & Anaerobe Facultative & Microaerofil & Anaerobe Facultative & Anaerobe Facultative \\
\hline Motility & $n / d$ & + & + & - \\
\hline Catalase & + & + & + & + \\
\hline Oxidase & + & - & - & - \\
\hline Citric acid & - & - & - & + \\
\hline Glucose & + & + & + & + \\
\hline Lactose & - & + & + & - \\
\hline Sucrose & - & - & - & - \\
\hline TSIA medium & Red-Yellow & Red-Yellow & Red-Yellow & Red-Yellow \\
\hline
\end{tabular}

Note: $n / d$ : undefined

\section{Morphological and biochemical characterization of mercury resistant microbes}

The four isolates had different colony morphology, which indicated diversity at the species level (Table 3). Meanwhile, based on the cell morphology observation, the isolates code $\mathrm{Hg} 37$ and $\mathrm{Hg} 43$ had the same coccus shape, and the $\mathrm{Hg} 44$ isolate is bacil shape. $\mathrm{Hg} 37$ and $\mathrm{Hg} 43$ were Gram-positive bacteria, while $\mathrm{Hg} 44$ was Gram-negative bacteria. In general, both Gram-positive and Gram-negative were reported to have mer genes that regulate the mercury resistance mechanism. The family of mer genes could be discovered in both bacterial groups' genome or plasmids (Barkay et al. 2003). However, Kannan and Krishnamoorthy (2006) stated that the isolated Gramnegative bacteria with bacilliform exhibits lower resistance to heavy metals than Gram-positive bacteria. In contrast, Chasanah et al. (2018) reported that Gram-negative bacteria were more resistant and dominant to pollutants than Gram-positive bacteria.

Based on the growth environment, the four isolates could grow at a pH of 4-8. Dash et al. (2013) reported the isolate that can volatilize mercury efficiently under environmental parameters, $\mathrm{pH}$ of 7 to 8 . The $\mathrm{pH}$ is an essential factor affecting microbial growth. It strongly influences abiotic factors, such as carbon availability, nutrient availability, and metals' solubility (Rousk et al. 2009). Kannan and Krishnamoorthy (2006) reported that the increased $\mathrm{pH}$ (above 9) would inhibit the organomercurial lyase enzyme activity and usually stimulate deprotonation of microbial surfaces.

The three isolates $(\mathrm{Hg} 32, \mathrm{Hg} 43$, and $\mathrm{Hg} 44)$ grew in the facultative anaerobic state, and only the $\mathrm{Hg} 37$ isolate grew under microaerophilic conditions. It is influenced by isolation techniques carried out in aerobic conditions. Mercury cycle can be found in various ecosystems, including soil, water, and sediment (Obrist et al. 2018; Hindersah et al 2018b). Its process was significantly influenced by the biological activities of the microbial community played in various oxic and anoxic reactions (Barkay and Wagner-Döbler 2005). Exploring mercuryreducing bacteria is very important because it shows facilitated $\mathrm{Hg}$ (II) transport activity under aerobic and anaerobic conditions (Schaefer et al. 2011).

Biochemical tests showed that all isolates were positive for catalase and glucose fermentation tests but negative for sucrose fermentation tests. Only $\mathrm{Hg} 37$ and $\mathrm{Hg} 43$ isolates were able to ferment lactose. In the oxidase and citric acid test, only $\mathrm{Hg} 32$ and $\mathrm{Hg} 44$ showed positive results. All oxidase-positive bacteria were aerobic and can use oxygen as a terminal electron acceptor in respiration. Bacteria which were oxidase-negative can be anaerobic, aerobic, or anaerobe facultative bacteria. The negative oxidase result shows that these organisms do not have cytochrome c oxidase activity. Imron et al. (2019) reported mercuryresistant bacteria characteristics were positive for glucose fermentation and citric utilization and negative for lactose and sucrose fermentation. Chasanah et al. (2015) said that four isolates of mercury-resistant microbes were negative to citric and lactose utilization, only one positive to oxidase test, and only one harmful to sucrose fermentation.

\section{Molecular characteristic of gene 16S rRNA and ITS region}

The identification of selected isolates was performed by several morphological and biochemical tests followed by molecular characterization. Because there was one strain indicated as mold, and three strains were bacteria based on their morphological and biochemical characteristics. So molecular identification was based on two genes, consisting of 16S rRNA for bacteria and ITS region for mold. Based on 16S rRNA sequences, three microbial strains had been identified as Mycobacterium sp. (strain $\mathrm{Hg} 43$ ), Mycolicibacterium peregrinum (strain $\mathrm{Hg} 37$ ), and Methylobacterium radiotolerans (strain $\mathrm{Hg} 44$ ) (Figure 3). 
Meanwhile, strain $\mathrm{Hg} 32$ was identified as a mold, Cladosporium sphaerospermum, based on ITS 3 sequences (Figure 4). As shown in Figure 3, M. peregrinum $\mathrm{Hg} 37$ and Mycobacterium sp. $\mathrm{Hg} 43$ were still one genera with a very close relationship. Meanwhile, M. radiotolerans $\mathrm{Hg} 44$ had the most distant relatives from the three and has a relatively higher closeness to Brevundimonas sp. $\mathrm{HgP} 1$ and $\mathrm{HgP} 2$ (JX009135 and JX009136) isolated by Irawati et al. (2012). It indicates that the level of similarity of morphological and biochemical characters is completely unrelated to their ability to defend against mercury exposure.
The Mycobacterium sp. $\mathrm{Hg} 43$ and M. peregrinum $\mathrm{Hg} 37$ are members of the phylum Actinobacteria. Meanwhile, Methylobacterium radiotolerans $\mathrm{Hg} 44$ is a member of Proteobacteria. Long-term mercury contamination could drive microbiota composition change in microcosm. Both phyla can survive microbiota composition changes and have a high population in mercury-contaminated soil (Frossard et al. 2018; Najar et al. 2020; Zhu et al. 2021). Even these phyla proportions in the contaminated soil relatively increased compared to other microbial groups in several cases (Mahbub et al. 2020).
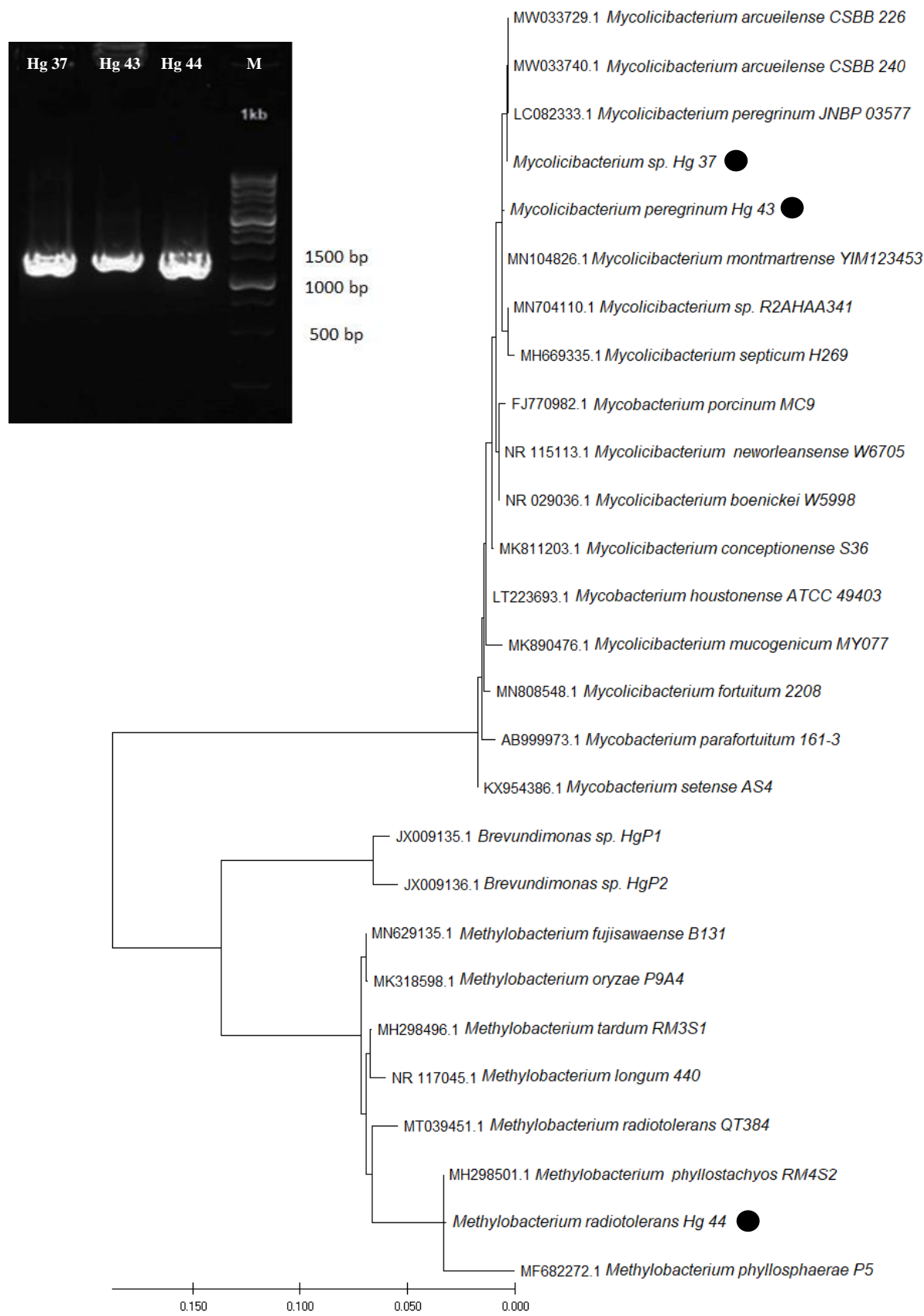

Figure 3. Phylogenetic tree of Mycobacterium sp. $\mathrm{Hg}$ 43, Mycolicibacterium peregrinum $\mathrm{Hg}$ 37, and Methylobacterium radiotolerans $\mathrm{Hg} 44$, based on 16s rRNA. The tree is drawn to scale, with branch lengths in the same units as those of the evolutionary distances used to infer the phylogenetic tree. The evolutionary distances are in the units of the number of base substitutions per site. 


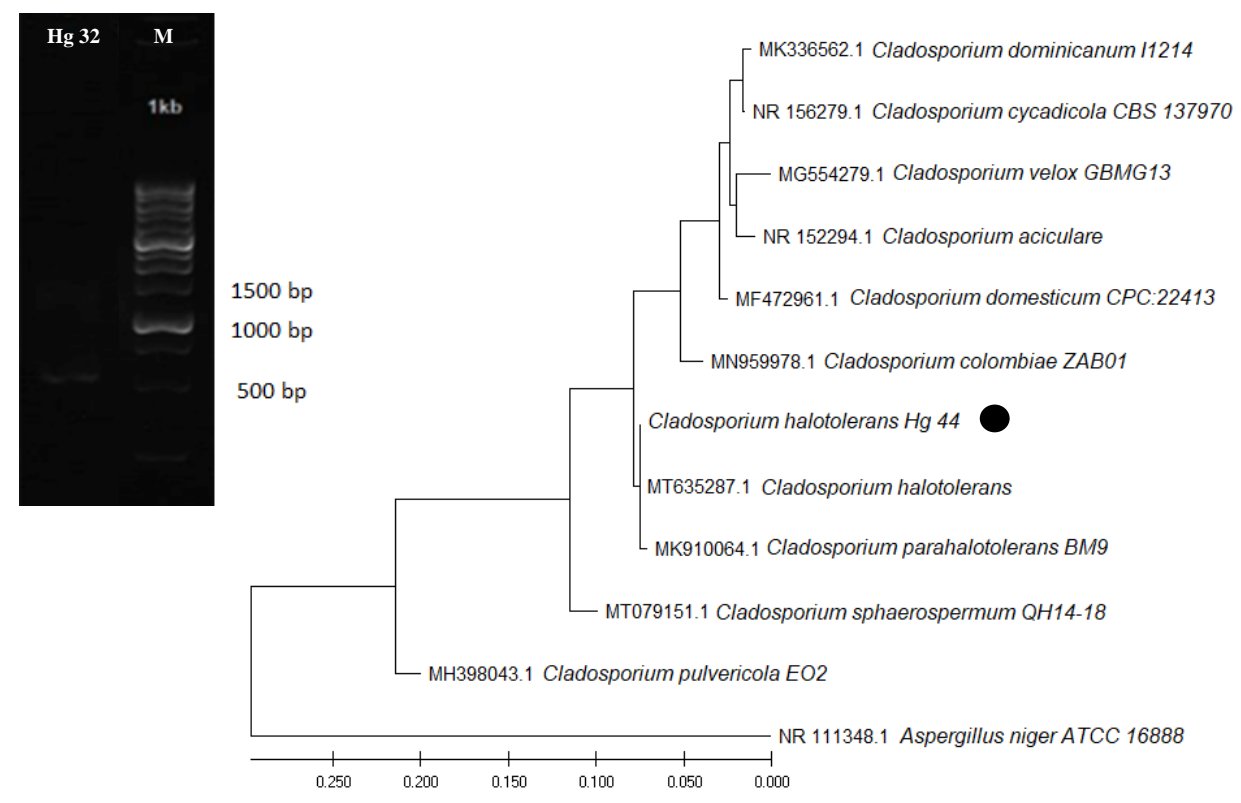

Figure 4. Phylogenetic tree of Cladosporium sphaerospermum $\mathrm{Hg} 32$ based on ITS 3. The tree is drawn to scale, with branch lengths in the same units as those of the evolutionary distances used to infer the phylogenetic tree. The evolutionary distances are in the units of the number of base substitutions per site.

Several factors cause composition change, including limitation of horizontal gene transfer, specific mercury resistant mechanism, and soil characteristic related mercury mobilization (Thomas and Nielsen 2005; Naguib et al. 2018; Wang et al. 2020). Meanwhile, C. sphaerospermum is a mold species often found in soil ecosystems. C. sphaerospermum has been reported in various agricultural fields and has an essential role in increasing plant growth by producing volatile organic compounds (MVOCs). These compounds may bind to metal ions in the soil in certain circumstances (Hamayun et al. 2009; Li et al. 2020). Even though mercury resistance mechanisms in fungi have not yet been fully elucidated, resistance fungi with the ability to degrade mercury have been reported, such as Cladosporium cladosporioides, which resistant towards $\mathrm{Hg}^{+2}$ because of bio-volatilization as the primary mechanism (Pietro-Souza et al. 2017).

\section{Mercury removal by resistant isolates}

The high mercury resistance levels indicated that the strain would be more promising for detoxifying mercury, thus the test was narrowed by selecting the two strains with the highest performance, i.e. Cladosporium halotolerans $\mathrm{Hg} 32$ and Mycolicibacterium peregrinum $\mathrm{Hg} 37$ for further experiment. Nevertheless, the isolates were not selected because the resistance ability was not always correlated with mercury's detoxification efficiency in some studies (Mangesa et al. 2019). The selection was made after the identification and construction process of phylogenetic trees to observe the correlation between kinship and the ability of microbial resistance to mercury. The phylogenetic tree indicates that the close genetic relationship level does not correlate with microbes' resistance (Figure 5). It strengthens the possibility of a disjunction between genetic data and microbes' ability to degrade mercury, including the relationship with the level of resistance of bacteria to mercury exposure.

The two strains have similar abilities at low concentrations below $10 \mathrm{mg} \mathrm{\textrm {L } ^ { - 1 }}$. At a mercury concentration of $10 \mathrm{mg} \mathrm{L}^{-1}, 80.30 \%$ of the mercury was removed by C. halotolerans $\mathrm{Hg} 32$ and $77.1 \%$ of mercury removed by $M$. peregrinum $\mathrm{Hg} 37$ (Figure 5). The $C$. halotolerans $\mathrm{Hg} 32$ and $M$. peregrinum $\mathrm{Hg} 37$ showed different mercury removal patterns. The ability of $C$. halotolerans $\mathrm{Hg} 32$ to remove mercury increased when the concentration raised up to $100 \mathrm{mg} \mathrm{L}^{-1}$ which reached $90.72 \%$ efficiency then stable as the mercury level increased. While, the M. peregrinum $\mathrm{Hg} 37$ removal ability decreased periodically when mercury concentration increased. Both strains have high mercury removal ability compared to previous reports ranging from 70 to $90 \%$ removal efficiency (Saranya et al. 2017). Typically, mercury removal ability will increase following mercury initial concentration up to a particular limit but will steady or decrease if the mercury concentration beyond limit circumstances (Upadhyay et al. 2017). However, according to this study, there was a strain, C. halotolerans $\mathrm{Hg} 32$, which preserved its ability to detoxify mercury at $3000 \mathrm{mg}$ $\mathrm{L}^{-1}$ exposure. 


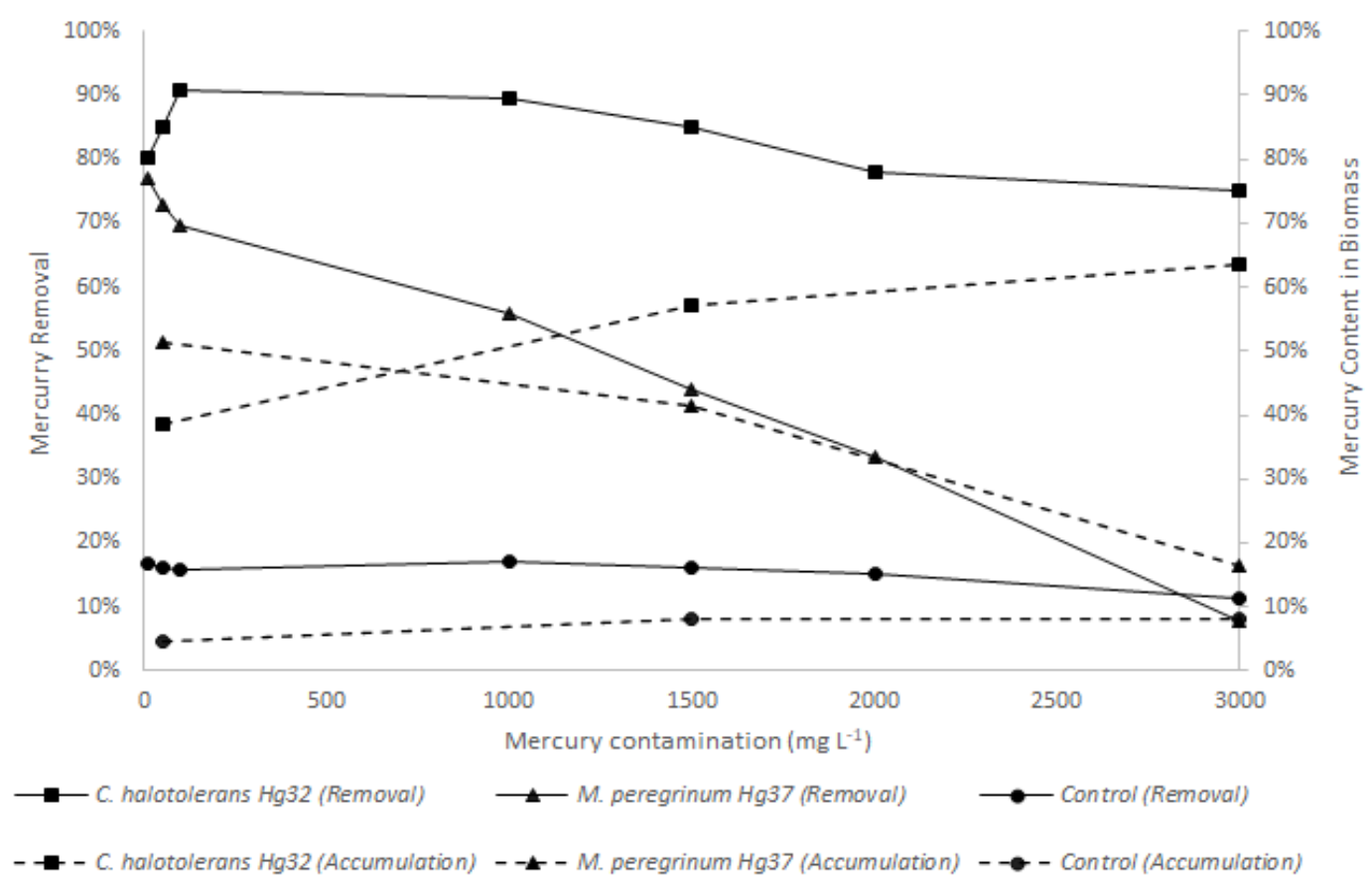

Figure 5. Percentage of removal of $\mathrm{Hg}^{2+}$ from solution following treatment with Cladosporium halotolerans $\mathrm{Hg} 32$ and Mycolicibacterium peregrinum $\mathrm{Hg} 37$ at the various concentrations

According to mercury accumulation in biomass, $M$. peregrinum $\mathrm{Hg} 37$ can accumulate higher mercury amounts in low concentration $\left(<50 \mathrm{mg} \mathrm{L}^{-1}\right)$ than $C$. halotolerans $\mathrm{Hg} 32$. Then, the accumulation ability of $M$. peregrinum Hg37 would fall gradually following a decrease in mercury removal ability due to most bacterial cells unable to survive at high mercury exposure. Meanwhile, $C$. halotolerans had an opposite accumulation trend and was positively correlated with a decrease in removal ability. increase in mercury concentration. The $M$. peregrinum $\mathrm{Hg} 37$ was assumed to have the ability to uptake soluble mercury and transform it into cell biomass as the main detoxifying mechanism. On the other hand, mercury content in biomass also proved that there is a possibility that $C$. halotolerans Hg32 had another mechanism besides mercury accumulation. It was indicated by the mercury accumulation in low concentration that there was a gap between mercury loss in solution and accumulated mercury in biomass.

Generally, fungi have a higher resistant-mercury ability than bacteria. Some fungi had been reported to survive with a MIC of more than $1000 \mathrm{mg} \mathrm{L}^{-1}$. Besides enzymatic reactions, fungi can retain $\mathrm{Hg}$ and decrease metal uptake through their filaments. They can also secrete organic acid to increase heavy metal mobilization (Hindersah et al. 2018a). Urík et al. (2014) reported that Cladosporium volatilized almost $80 \%$ of initial mercury content during 7 day static cultivation in the dark. Mercury bio-volatilization is the major filamentous fungal detoxification mechanism rather than its deposition or efflux in non-volatile forms. In the last updated study of fungal mercury resistance, the highest mercury concentration tested is $600 \mathrm{mg} \mathrm{mL}^{-1}$ towards two genera of endophytic fungi (Pietro-Souza et al. 2020).

The detoxification stability of $C$. halotolerans $\mathrm{Hg} 42$ indicates that it has a specific mercury bioremediation mechanism activated by the presence and amount of mercury. It's regulation was also reported in Westerdykella sp. P71 has a particular resistance mechanism activated by mercury's existence and amount (Sun et al. 2017). However, whether $C$. halotolerans $\mathrm{Hg} 42$ has the same relationship pattern remains uncertain. There is a possibility that $C$. halotolerans $\mathrm{Hg} 32$ also has another mechanism apart from its mercury detoxification mechanism which allows stable detoxification processes amid increasing mercury concentrations.

The Mycolicibacterium peregrinum $\mathrm{Hg} 37$ has almost similar mercury degradation efficiency to $C$. halotolerans $\mathrm{Hg} 32$ strains at concentrations below $10 \mathrm{mg} \mathrm{L}^{-1}$. However, as mercury exposure increases, its degradation ability decreases further down to $10 \%$. The $M$. peregrinum $\mathrm{Hg} 37$ is gram-negative bacteria, which generally have $m e r D$ as a gene repressor. It can relate to $M$. peregrinum's ability to decrease along with mercury concentration increase. In exploratory studies of mercury degradation, genus Mycolicibacterium is relatively rarely reported to have the ability to detoxify mercury compared to various other genera, such as Brevundimonas, Klebsiella, Pseudomonas, Serratia, Streptococcus, and Enterococcus (Pushkar et al. 2019; Kepel et al. 2020). However, Augelletti et al. (2020) have reported the results of gene sequences of various genes related to resistance to heavy metals in Mycolicibacterium frederiksbergense, including copper ( $c o p A, \quad \operatorname{cop} C$, and $\operatorname{copD})$, arsenic (arsRBCDA), and 
mercury (merA and merB). Furthermore, Barrio-Duque et al. (2020) also reported that Mycolicibacterium has several gene copies that have implications for plant resistance, including arsenic, mercury, chromium, copper, cadmium, cobalt, and zinc. It shows the potential for genus Mycolicibacterium to be obtained as a bioaugmentation agent for heavy metals, including mercury in contaminated soil.

\section{The motility of $C$. carpio and $G$. affinis in mercury decontaminated water}

In the high mercury concentration level, there are significant relations between the mercury chloride concentration and the mortality rate of organisms (Gupta and Jawale 2013). It is inspired to design bioassay tests to confirm the effectiveness of the mercury decontamination process. We confirmed that the two selected isolates did not have pathogenicity to fish in previous experiments. Cyprinus carpio and Gambusia affinis were used in this study because they are sensitive to environmental conditions and are often used in standard bioassay procedures. Two fish species were placed on mercurycontaminated water that had been incubated using mercuryreducing microbial strains (Figure 6).
In this study, $C$. Carpio was incubated in water containing $0.1 \mathrm{mg} \mathrm{L}^{-1}$ mercury which was decontaminated by using $C$. halotolerans $\mathrm{Hg} 32$ and M. peregrinum $\mathrm{Hg} 37$. Meanwhile, G. affinis specimens were incubated in water containing $0.08 \mathrm{mg} \mathrm{L}^{-1}$. The $G$. affinis was incubated at lower concentrations due to their lower lethal concentration level than C. Carpio (Ahmad 2011). Gupta and Jawale (2013) have reported that $G$. affinis have 96-h LC50 by $0,097 \mathrm{mg} \mathrm{L}^{-1}$ and $96-\mathrm{h} \mathrm{LC} 100$ by $0.148 \mathrm{mg} \mathrm{L}^{-1}$. The bioassay results showed that the mortality rate of both $C$. Carpio and G. affinis were significantly lower compared to the control that was not incubated with microbial strains which no mortality was observed during the testing period in the negative controls (without $\mathrm{HgCl}_{2}$ contamination). Mercury existence exceeding lethal concentration can cause the death of fish. It is related to toxic effects produced by protein precipitation, enzyme inhibition, and generalized corrosive action (Bjørklund et al. 2017). Water that has been treated with microbes can maintain a mortality rate of less than $5 \%$. It indicates a mercury degradation effectiveness of the two bacterial isolates, $C$. halotolerans $\mathrm{Hg} 42$ and M. peregrinum $\mathrm{Hg} 37$.
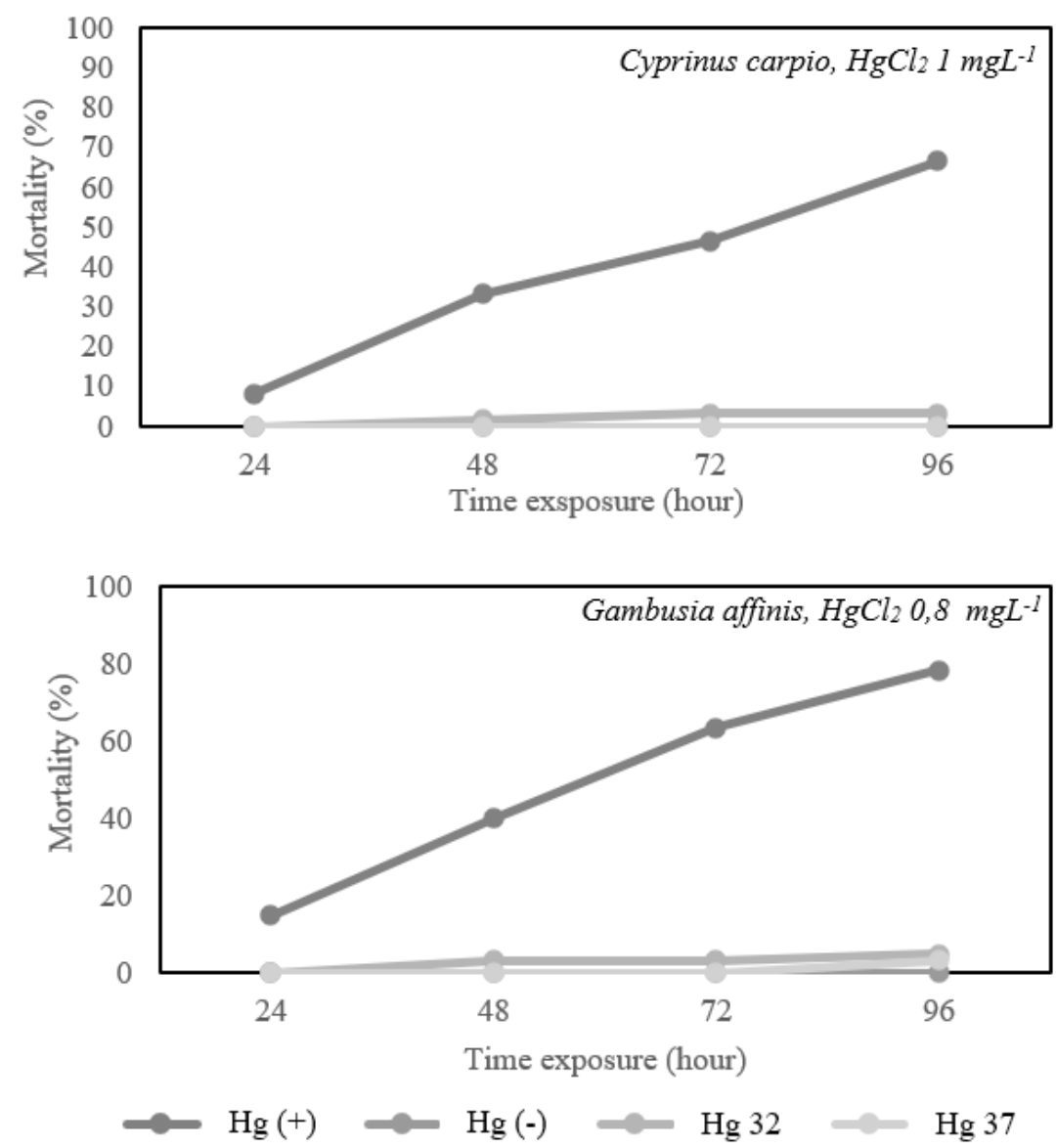

Figure 6. Percentage mortality of Cyprinus carpio and Gambusia affinis and after 96 h exposure to $\mathrm{HgCl}_{2}$. $\mathrm{Hg}(+)$ : contaminated water (negative control), $\mathrm{Hg}(-)$ : noncontaminated water (positive control), $\mathrm{Hg}$ 32: decontaminated water using Cladosporium halotolerans $\mathrm{Hg} 32, \mathrm{Hg}$ 37: decontaminated water using Mycolicibacterium peregrinum $\mathrm{Hg} 37$. 
In conclusion, microbes with higher resistant mercury levels have been discovered during the present study from the Mount Pongkor area. Data showed that four isolates could survive in the conditions with more than $600 \mathrm{mg} \mathrm{L}^{-1}$ with two strains that have survivability at $3000 \mathrm{mg} \mathrm{L}^{-1}$ of $\mathrm{HgCl}_{2}$. Based on morphological, biochemical and molecular characteristics, the strains with highest tolerance level were identified as Cladosporium halotolerans $\mathrm{Hg} 32$ (mold) and Mycolicibacterium peregrinum $\mathrm{Hg} 37$ (bacterial strain). Quantitative analysis of mercury removal confirmed that both strains have the ability to detoxify mercury. The C. halotolerans $\mathrm{Hg} 32$ and M. peregrinum $\mathrm{Hg} 37$ have different mercury degradation patterns influenced by increased mercury exposure. Even though $C$. halotolerans $\mathrm{Hg} 32$ have the best removal ability at $100 \mathrm{mg}$ $\mathrm{L}^{-1}$ of $\mathrm{HgCl}_{2}$, it can still remove mercury at high concentrations up to $3000 \mathrm{mg} \mathrm{L}^{-1}$ with $75 \%$ removal efficiency. Meanwhile, M. peregrinum $\mathrm{Hg} 37$ has best performance at $10 \mathrm{mg} \mathrm{L}-1$ of $\mathrm{HgCl}_{2} \quad(77 \%$ removal efficiency), and dropped with increasing mercury exposure level. The removal mechanism was also confirmed by a fish bioassay study in mercury-contained water detoxified by both strains. Both strains were confirmed to reduce mercury levels, proven by low fish mortality. We estimate that the two strains have interesting mercury detoxification mechanisms to advanced studies. The explanation regarding it needs to be elaborated further up to the molecular level. Overall, we can conclude that both strains have great potential to be developed as bioremediation agents in environments exposed to mercury. The difference in characteristics of both strains in mercury detoxification can be considered for designing bioremediation applications in the field.

\section{ACKNOWLEDGEMENTS}

The authors would like to acknowledge the Soil Biotechnology Laboratory, Soil Science and Land Resources Department Faculty of Agriculture, IPB University, for funding this research project and providing necessary facilities as part of the environmental biotechnology course.

\section{REFERENCES}

Abdallah MAM. 2020. Mercury speciation in aquatic environment southeastern coast of the Mediterranean Sea, Egypt. Emerg Contam 6: 194-203. DOI:10.1016/j.emcon.2020.04.003.

Ahmad Z. 2011. Acute toxicity and haematological changes in common carp (Cyprinus carpio) caused by diazinon exposure. Afr J Biotechnol 10 (63): 13852-13859. DOI: 10.5897/AJB11.1247.

Augelletti F, Tremblay J, Agathos SN, Jousset A, Stenuit B. 2020. Draft whole-genome sequence of the anthracene-degrading strain Mycolicibacterium frederiksbergense LB501T, isolated from a polycyclic aromatic hydrocarbon-contaminated soil. Microbiol Resour Announc 9 (43): e00671-20. DOI: 10.1128/MRA.00671-20.

Barkay T, Miller SM, Summers AO. 2003. Bacterial mercury resistance from atoms to ecosystems. FEMS Microbiol Rev 27 (2-3): 355-84. DOI: 10.1016/S0168-6445(03)00046-9.

Barkay T, Wagner-Döbler I. 2005. Microbial transformations of mercury: potentials, challenges, and achievements in controlling mercury toxicity in the environment. In: Allen I, Laskin JWB, Geoffrey MG (eds) Adv Appl Microbio, vol 57. Academic Press, New York. DOI: 10.1016/S0065-2164(05)57001-1.

Barrio-Duque A, Samad A, Nybroe O, Antonielli L, Sessitsch A, and Compant S. 2020. Interaction between endophytic Proteobacteria strains and Serendipita indica enhances biocontrol activity against fungal pathogens. Plant Soil 451: 277-305. DOI: 10.1007/s11104020-04512-5.

Bjørklund G, Dadar M, Mutter J, Aaseth J. 2017. The toxicology of mercury: Current research and emerging trends. Environ Res 159: 545-554. DOI: 10.1016/j.envres.2017.08.051

Cappuccino JG, Sherman N. 2002. Techniques for Isolation of Pure Culture. Microbiology: A Laboratory Manual, 6th edn. Pearson Education Inc., Singapore.

Chasanah U, Nuraini Y, Handayanto E. 2018. The potential of mercuryresistant bacteria isolated from small-scale gold mine tailings for accumulation of mercury. J Ecol Eng 19 (2). DOI: $10.12911 / 22998993 / 83565$.

Dash HR, Mangwani N, Das S. 2013. Characterization and potential application in mercury bioremediation of highly mercury-resistant marine bacterium Bacillus thuringiensis PW-05. Environ Sci Pollut Res 21 (4): 2642-2653. DOI: 10.1007/s11356-013-2206-8.

Du H, Sun T, Liu Y, An S, Xie H, Wang D, Igarashi Y, Imanaka T, Luo F, Ma M. 2021. Bacteria and archaea involved in anaerobic mercury methylation and methane oxidation in anaerobic sulfate-rich reactors. Chemosphere 274: 129773. DOI: 10.1016/j.chemosphere.2021.129773.

Ekyastuti W, Setyawati TR. 2015. Identification and in vitro effectiveness test of four isolates of mercury-resistant bacteria as bioaccumulation agents of mercury. Procedia Environ Sci 28: 258-264. DOI: 10.1016/j.proenv.2015.07.033.

Febria FA, Zakaria IJ, Syukriani L, Rahayu SP, Fajri MA. 2016. The highest mercury resistant bacteria as a mercury remediator from gold mining soil in West Sumatera, Indonesia. J Chem Pharm Res 8 (1): 394-397.

Frossard A, Donhauser J, Mestrot A, Gygax S, Bååth E, Frey B. 2018. Long- and short-term effects of mercury pollution on the soil microbiome. Soil Biol Biochem 120: 191-199. DOI: 10.1016/j.soilbio.2018.01.028.

Ginting RCB, Solihat N, Hafsari AR, Irawan. 2021. Potential bacteria capable of remediating mercury-contaminated soils. IOP Conf Ser: Earth Environ Sci 648 (1): 012136. DOI: 10.1088/17551315/648/1/012136.

Gupta SS, Jawale CS. 2013. Determination of median tolerance limit (LC50) of Gambusia affinis for mercuric chloride and its behavioral impacts. DAV Intl J Sci 2 (1): 93-98.

Hamayun M, Khan SA, Khan AL, Shin JH, Ahmad B, Shin DH. 2010. Exogenous gibberellic acid reprograms soybean to higher growth and salt stress tolerance. J Agric Food Chem 58: 7226-7232. DOI: 10.1021/jf101221t.

Harley JP, Prescott LM. 2005. Laboratory Exercises in Microbiology, 6th Edition. The McGraw Hill Higher Education, Boston, MA.

Hindersah R, Mulyani O, Osok R. 2017. Proliferation and exopolysaccharide production of Azotobacter in the presence of mercury. Biodivers J 8 (1): 21-26.

Hindersah R, Asda KR, Herdiyantoro D, NN Kamaluddin. 2018a. Isolation of mercury-resistant fungi from mercury-contaminated agricultural soil. Agriculture 8 (3). DOI: 10.3390/agriculture8030033.

Hindersah R, Risamasu R, Kalay AM, Dewi T, Makatita I. 2018 b. Mercury contamination in soil, tailing and plants on agricultural fields near closed gold mine in Buru Island, Maluku. J Degraded Mining Lands Manag 5 (2): 1027-1034. DOI: 10.15243/jdmlm.2018.052.1027.

Imron MF, Kurniawan SB, Soegianto A. 2019. Characterization of mercury-reducing potential bacteria isolated from Keputih non-active sanitary landfill leachate, Surabaya, Indonesia under different saline conditions. J Environ Manag 241: 113-122. DOI: 10.1016/j.jenvman.2019.04.017.

Irawati W, Soraya Y, Baskoro AH. 2012. A study on mercury-resistant bacteria isolated from a gold mine in Mount Pongkor Village, Bogor, Indonesia. Hayati J Biosci 19 (4): 197-200. DOI: 10.4308/hjb.19.4.197.

Ismawati Y, Jindrich P, Digangi J. 2013. Mercury Hotspots in Indonesia. IPEN Mercury-Free Campaign Report. BaliFokus (Indonesia) Arnika Association (Czech Republic) - IPEN Heavy Metals Working Group, Denpasar. DOI: 10.13140/RG.2.2.26150.73282.

Ismawati Y, Lelitasari, Buftheim S. 2015. Gold production in rural areas of Bogor Regency and its hidden hazards implication. The 5th Environmental Technology and Management Conference "Green 
Technology towards Sustainable Environment”, Bandung, Indonesia. [Indonesian]

Juliawan N. 2006. Distribution of Mercury in mining areas in Mount Pongkor, Bogor District, West Java. Proceeding of Disclosure of The Results of Field and Non-field Activities in 2006, Center of Geological Resources. Ministry of Energy and Mineral Resources of the Republic of Indonesia, Jakarta. [Indonesian]

Kannan SK, Krishnamoorthy R. 2006. Isolation of mercury resistant bacteria and influence of abiotic factors on bioavailability of mercury - a case study in Pulicat Lake north of Chennai, South East India. Sci Total Environ 367 (1): 341-353. DOI: 10.1016/j.scitotenv.2005.12.003

Kepel BJ, Gani MA, Tallei TE. 2020. Comparison of bacterial community structure and diversity in traditional gold mining waste disposal site and rice field by using a metabarcoding approach. Intl J Microbiol. DOI: $10.1155 / 2020 / 1858732$.

Kiran MG, Pakshirajan K, Das G. 2017. Heavy metal removal from multicomponent system by sulfate-reducing bacteria: Mechanism and cell surface characterization. J Hazard Mater 324: 62-70. DOI 10.1016/j.jhazmat.2015.12.042

Krisnayanti BD, Anderson CW, Utomo WH, Feng X, Handayanto E, Mudarisna N, Ikram H. 2012. Assessment of environmental mercury discharge at a four-year-old artisanal gold mining area on Lombok Island, Indonesia. J Environ Monit 14 (10): 2598-2607.

Larkin MA, Blackshields G, Brown NP, Chenna R, McGettigan PA, McWilliam H, Valentin F, Wallace IM, Wilm A, Lopez R, Thompson JD. (2007). Clustal W and Clustal X version 2.0. Bioinformatics 23 (21): 2947-2948. DOI: 10.1093/bioinformatics/btm 404

Li J, Zhang M, Sun J, Mao X, Wang J, Liu H, Zheng H, Li X, Zhao H, Zou D. 2020. Heavy metal stress-associated proteins in rice and arabidopsis: Genome-wide identification, phylogenetics, duplication, and expression profiles analysis. Front Genet 11: 477. DOI: 10.3389/fgene.2020.00477.

Mahbub KR, King WL, Siboni N, Nguyen VK, Rahman MM, Megharaj M, Seymour JR, Franks AE, Labbate M. 2020. Long-lasting effect of mercury contamination in the soil microbiome and its co-selection of antibiotic resistance. Environ Pollut. DOI: 10.1016/j.envpol.2020.115057.

Mangesa R, Kasmawati K, Darma D, Lisaholit S, Setiaji Ab, Umanailo MCB. 2019. Identification and testing resistance against bacteria isolated mercury from gold mining in Gogorea Buru. Int $\mathrm{J} \mathrm{Sci}$ Technol Res 8 (11): 5-8.

Naguib MM, El-Gendy AO, Khairalla AS. 2018. Microbial diversity of mer operon genes and their potential rules in mercury bioremediation and resistance. Open Biotech J 12 (1). DOI: 10.2174/1874070701812010056.

Naguib MM, Khairalla AS, El-Gendy AO, Elkhatib WF. 2019. Isolation and characterization of mercury-resistant bacteria from wastewate sources in Egypt. Can J Microbiol 65 (4): 308-321. DOI: 10.1139/cjm-2018-0379

Najar IN, Sherpa MT, Das S, Das S, Thakur N. 2020. Diversity analysis and metagenomic insights into the antibiotic resistance and metal resistances among Himalayan hot spring bacteriome- insinuating inherent environmental baseline levels of antibiotic and metal tolerance. J Glob Antimicrob Resist. DOI: 10.1016/j.jgar.2020.03.026

Obrist D, Kirk JL, Zhang L, Sunderland EM, Jiskra M, Selin NE. 2018. A review of global environmental mercury processes in response to human and natural perturbations: Changes of emissions, climate, and land use. Ambio 47: 116-140. DOI: 10.1007/s13280-017-1004-9.

Pietro-Souza W, Mello IS, Vendruscullo SJ, Silva GFD, Cunha CND, White JF, Soares MA. 2017. Endophytic fungal communities of Polygonum acuminatum and Aeschynomene fluminensis are influenced by soil mercury contamination. PloS One 12 (7): e0182017. DOI: 10.1371/journal.pone.0182017.

Pietro-Souza W, de Campos Pereira F, Mello IS, Stachack FFF, Terezo AJ, Cunha CND, White JF, Li H, Soares MA. Mercury resistance and bioremediation mediated by endophytic fungi. Chemosphere 240: 124874. DOI: $10.1016 /$ j.chemosphere.2019.124874.

Pushkar B, Sevak P, Singh A. 2019. Bioremediation treatment process through mercury-resistant bacteria isolated from Mithi River. Appl Water Sci 9: 117. DOI: 10.1007/s13201-019-0998-5.

Rasmussen LD, Zawadsky C, Binnerup SJ, Oregaard G, Sorensen SJ, Kroer N. 2008. Cultivation of hard to culture subsurface mercuryresistant bacteria and discovery of new merA gene sequences. Appl Environ Microbiol 74: 3795-3803. DOI: 10.1128/AEM.00049-08.

Retnaningrum E, Wilopo W. 2017. Removal of sulphate and manganese on synthetic wastewater in sulphate reducing bioreactor using Indonesian natural zeolite. Indon J Chem 17 (2): 203-210. DOI: 10.22146/ijc. 22710

Rousk J, Brookes PC, Baath E. 2009. Contrasting soil pH effects on fungal and bacterial growth suggest functional redundancy in carbon mineralization. Appl Environ Microbiol 75 (6): 1589-1596. DOI: 10.1128/AEM.02775-08.

Saranya K, Sundaramanickam A, Shekhar S, Swaminathan S, Balasubramanian T. 2017. Bioremediation of mercury by Vibrio fluvialis screened from industrial effluents. BioMed Res Intl 2017: 6509648. DOI: 10.1155/2017/6509648.

Schaefer JK, Rocks SS, Zheng W, Liang L, Gu B, Morel FM. 2011. Active transport, substrate specificity, and methylation of $\mathrm{Hg}$ (II) in anaerobic bacteria. Proc Natl Acad Sci USA 108 (21): 8714-8719. DOI: $10.1073 /$ pnas. 1105781108 .

Suhartini, Abubakar. 2017. Socio-economic impacts and policy of artisanal small-scale gold mining in relation to sustainable agriculture: a case study at Sekotong of West Lombok. J Degraded Mining Lands Manag 4 (3): 789-796. DOI: $10.15243 / \mathrm{jdmlm} .2017 .043 .789$.

Sumantri A, Laelasari E, Junita NR, Nasrudin N. 2014. Logam merkuri pada pekerja penambangan emas tanpa izin. Kesmas: Natl Publ

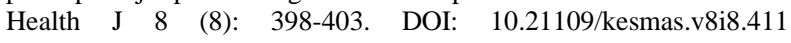
[Indonesian]

Sun Y, Aguila B, Perman J, Earl LD, Abney CW, Cheng Y, Wei H, Nguyen N, Wojtas L, Ma S. 2017. Postsynthetically modified covalent organic frameworks for efficient and effective mercury removal. J Am Chem Soc 139: 2786-2793. DOI: 10.1021/jacs.6b12885.

Tamura K, Stecher G, Peterson D, Filipski A, Kumar S. 2013. MEGA6: Molecular Evolutionary Genetics Analysis version 6.0. Mol Biol Evol 30 (12): 2725-2729. DOI: $10.1093 / \mathrm{molbev} / \mathrm{mst} 197$.

Thomas CM, Nielsen KM. 2005. Mechanisms of, and barriers to, horizontal gene transfer between bacteria. Nat Rev Microb 3: 711721. DOI: $10.1038 /$ nrmicro1234.

Upadhyay KH, Vaishnav AM, Tipre DR, Patel BC, Dave SR. 2017. Kinetics and mechanisms of mercury biosorption by an exopolysaccharide producing marine isolate Bacillus licheniformis. 3 Biotech 7 (5): 313. DOI: 10.1007/s13205-017-0958-4.

Urík M, Hlodák M, Mikušová P, Matúš P. 2014. Potential of microscopic fungi isolated from mercury-contaminated soils to accumulate and volatilize mercury (II). Water Air Soil Pollut 225 (12): 1-11. DOI: 10.1007/s11270-014-2219-Z.

Wang L, Hou D, Cao Y, Ok YS, Tack FMG, Rinklebe J, O'Connor D. 2020. Remediation of mercury-contaminated soil, water, and air: A review of emerging materials and innovative technologies. Environ Intl 134: 105281. DOI: 10.1016/j.envint.2019.105281.

Yoga GP, Lumbanbatu D, Riani E, Wardiatno Y. 2014. Pengaruh pencemaran merkuri di sungai Cikaniki terhadap biota Trichoptera (Insekta). Limnotek-Perairan Darat Tropis di Indonesia 21 (1). [Indonesian]

Zhu H, Teng Y, Wang X, Zhao L, Ren W, Luo Y, Christie P. 2021. Changes in clover rhizosphere microbial community and diazotrophs in mercury-contaminated soils. Sci Total Environ 767: 145473. DOI: 10.1016/j.scitotenv.2021.145473. 